\title{
A new Centromochlus Kner, 1858 (Siluriformes: Auchenipteridae: Centromochlinae) from the transition between Amazon floodplain and Guiana shield, Brazil
}

\author{
Luisa Maria Sarmento-Soares ${ }^{1,2}$, Henrique Lazzarotto ${ }^{3}$, Lucia Rapp Py-Daniel ${ }^{4}$ and \\ Rafael Pereira Leitão ${ }^{4}$
}

Species of Centromochlus are widely distributed in South America, with records for major basins such as the Amazon and Orinoco, rivers draining the Guiana Shield such as the Essequibo, Courantyne (Corantijn), Coppename, Maroni, and Oyapock, and Brazilian Shield drainages as upper Paraná and São Francisco. In the last four years, three species of Centromochlus have been described, raising the total number of valid species to sixteen. The new species of Centromochlus described herein is diagnosed by having black ground color sharply delimited from a white underside by conspicuous wavy border. The new species is recorded from the Nhamundá, left bank tributary to the lower Amazon that drain from the Brazilian portion of the Guiana Shield. Although apparently similar to some Tatia species (e.g. Tatia musaica, T. carolae and T. melanoleuca), the new species possess two conditions of the Weberian apparatus otherwise observed only in Centromochlus heckelii and C. existimatus among centromochlin catfishes. The new Centromochlus comprises small catfishes with adults ranging from 48 to $57 \mathrm{~mm}$ SL.

Espécies de Centromochlus têm ampla distribuição pela América do Sul, com registros para as principais bacias como o Amazonas e Orinoco, rios com drenagens no Escudo das Guianas como Essequibo, Corentyne, Copename, Maroni e Oiapoque, e ainda pelas drenagens do Escudo Brasileiro como Alto Paraná e São Francisco. Nos últimos quatro anos foram descritas três espécies de Centromochlus elevando o número de espécies válidas para dezesseis. A nova espécie de Centromochlus aqui descrita é diagnosticada pela presença de dorso escuro abruptamente separado de um ventre branco por uma barra ondulada conspícua. A nova espécie foi descoberta no rio Nhamundá um igarapé de água clara do baixo Amazonas com rede de drenagem a partir da porção brasileira do Escudo das Guianas. Apesar de aparentemente similar a algumas espécies de Tatia (e.g. Tatia musaica, T. carolae e T. melanoleuca), indivíduos da nova espécie apresentam uma morfologia particular do aparelho de Weber até então reportadas apenas para $C$. heckelii e $C$. existimatus, entre os bagres centromoclíneos, e que merecem maiores discussões. O novo Centromochlus inclui pequenos bagres com adultos entre 48 e $57 \mathrm{~mm} \mathrm{CP}$.

Keywords: Doradoidea, Ostariophysi, South America, Systematics, Tatia.

\section{Introduction}

The Auchenipteridae is composed of two monophyletic clades: Centromochlinae and Auchenipterinae (SoaresPorto, 1998; Akama, 2004; Birindelli, 2014). The Centromochlinae is one of the most well-supported clades in Auchenipteridae, and uniquely diagnosed by features associated with reproduction by insemination, such as: anal fin oblique relative to the body axis in mature males, urogenital papilla emerging from skin flap at anal-fin origin in adult males; anal-fin proximal radials partially or completely fused together forming a single ossification in mature males, and anal-fin proximal radials oblique relative to the body axis in mature males, not interdigitated with hemal spines (Ferraris, 1988, 2003; Soares-Porto, 1998; Birindelli, 2014). The genera Centromochlus Kner 1858, Gelanoglanis Böhlke 1980, Glanidium Lütken 1874 and Tatia Miranda Ribeiro 1911, constitute the subfamily Centromochlinae (Ferraris, 2007). In the last five years, several new species have been described in Centromochlinae, including three Centromochlus, one Gelanoglanis, one Glanidium, and three Tatia, for a total of 43 valid species within the subfamily.

\footnotetext{
${ }^{1}$ Instituto Nacional da Mata Atlântica, Av. José Ruschi, 4, Centro, 29650-000 Santa Teresa, ES, Brazil. luisa@nossosriachos.net (corresponding author)

${ }^{2}$ Programa de Pós-Graduação em Biologia Animal, Universidade Federal do Espírito Santo. Av. Fernando Ferrari, 514, Prédio Bárbara Weinberg, Campus Universitário Goiabeiras, 29043-900 Vitória, ES, Brazil.

${ }^{3}$ Universidade Federal do Rio de Janeiro (UFRJ), Laboratório de Ecologia de Peixes, Instituto de Biologia, Cidade Universitária, CCS, Bloco A, 21941-590 Rio de Janeiro, RJ, Brazil. kiko_lazzarotto@yahoo.com.br

${ }^{4}$ Instituto Nacional de Pesquisas da Amazônia. Av. André Araújo 2936, 69080-971 Manaus, AM, Brazil. (RPL) ecorafa@gmail.com, (LRP) lucia.rapp@gmail.com
} 
Species of Centromochlus are widely distributed in South America, occurring in the Orinoco basin in Venezuela and Colombia, Amazon basin from Ecuador to Brazil, coastal rivers of northern South America between the mouths of the Orinoco and Amazon rivers and upper Paraná and São Francisco basins (Soares-Porto, 1998; Ferraris, 2003, 2007; Akama \& Sarmento-Soares, 2007; Sarmento-Soares \& Buckup, 2005; Sarmento-Soares \& Birindelli, 2015).

At present, Centromochlus is a morphologically heterogeneous assemblage composed of 15 species supported by the presence of an elongate maxilla that extends into the maxillary barbel; elongate ventrolateral process of infraorbital 1, forming anterior border of orbit; and longitudinal crest on the parasphenoid and orbitosphenoid for attachment of the adductor arcus palatini (Soares-Porto, 1998; Sarmento-Soares \& Porto, 2006). In addition, the anterior nuchal plate is lacking in Gelanoglanis and some species of Centromochlus (Soares-Porto, 1998; SarmentoSoares \& Birindelli, 2015).

Recent fieldwork along the rio Nhamundá, Amazonas and Pará states, a clearwater tributary of the lower Amazon river draining the Guiana shield, revealed the presence of a new distinctively, colored, species of Centromochlus.

\section{Material and Methods}

Osteological features were examined in cleared and stained (CS) specimens prepared according to the procedures of Taylor \& Van Dyke (1985). Osteological data were obtained from radiographs for species poorly represented in ichthyological collections. Specimens examined as radiographs are noted as " $\mathrm{Rx}$ " in the Comparative Material section. Prior to clearing and staining, specimens were dissected to determine gut contents, sexual maturity of gonads, and myological characteristics. Osteological nomenclature follows the Teleost Anatomy Ontology (Dahdul et al., 2010), with exceptions based on Birindelli (2014). Orientation of dentations on pectoral-fin spine as in Vanscoy et al. (2015). Muscle names follow SarmentoSoares \& Porto (2006). Drawings of cleared and stained specimens were rendered by camera lucida. Photographs of structural details were taken using a digital camera coupled to a Leica stereomicroscope.

Straight-line measurements were made with digital calipers to the nearest $0.1 \mathrm{~mm}$. Measurements and counts follow Sarmento-Soares \& Martins-Pinheiro (2008). Counts of fin rays and bony elements were obtained from alcoholpreserved and CS specimens. Vertebral counts include the five elements incorporated into the Weberian complex plus one terminal element associated with the hypural complex (following Vari \& Ferraris, 2013). Counts of branchiostegal rays were performed only on CS specimens. Standard length (SL) is expressed in $\mathrm{mm}$ and all other measurements are expressed as percentage of the SL, except subunits of the head, which are expressed as percentage of the head length (HL).
Institutional abbreviations are as follows: American Museum of Natural History, New York(AMNH); TheAcademy of Natural Sciences of Philadelphia (ANSP); Illinois Natural History Survey, University of Illinois, Champaign, Illinois (INHS); Instituto Nacional de Pesquisas da Amazônia, Manaus (INPA); Instituto Nacional da Mata Atlântica [formely Museu de Biologia Professor Mello Leitão], Santa Teresa (MBML); Museo de Biología de la Universidad Central de Venezuela, Caracas (MBUCV-V); Museo de Ciencias Naturales de la Universidad de Los Llanos Occidentales Ezequiel Zamora - UNELLEZ, Guanare (MCNG); Museu Nacional, Rio de Janeiro (MNRJ); Museu de Zoologia da Universidade de São Paulo (MZUSP); Netherlands Centre for Biodiversity Naturalis [formerly Rijksmuseum van Natuurlijke Historie], Leiden (RMNH. PISC); National Museum of Natural History, Smithsonian Institution, Washington DC (USNM) and Zoölogisch Museum, Universiteit van Amsterdam [alternatively Zoological Museum Amsterdam], Leiden; now part of Netherlands Centre for Biodiversity Naturalis (ZMA).

\section{Results}

\section{Centromochlus orca, new species}

urn:1sid:zoobank.org:act:3C7F0FEA-CEBF-4FDA-A48962D8089E2DF9

Fig. 1

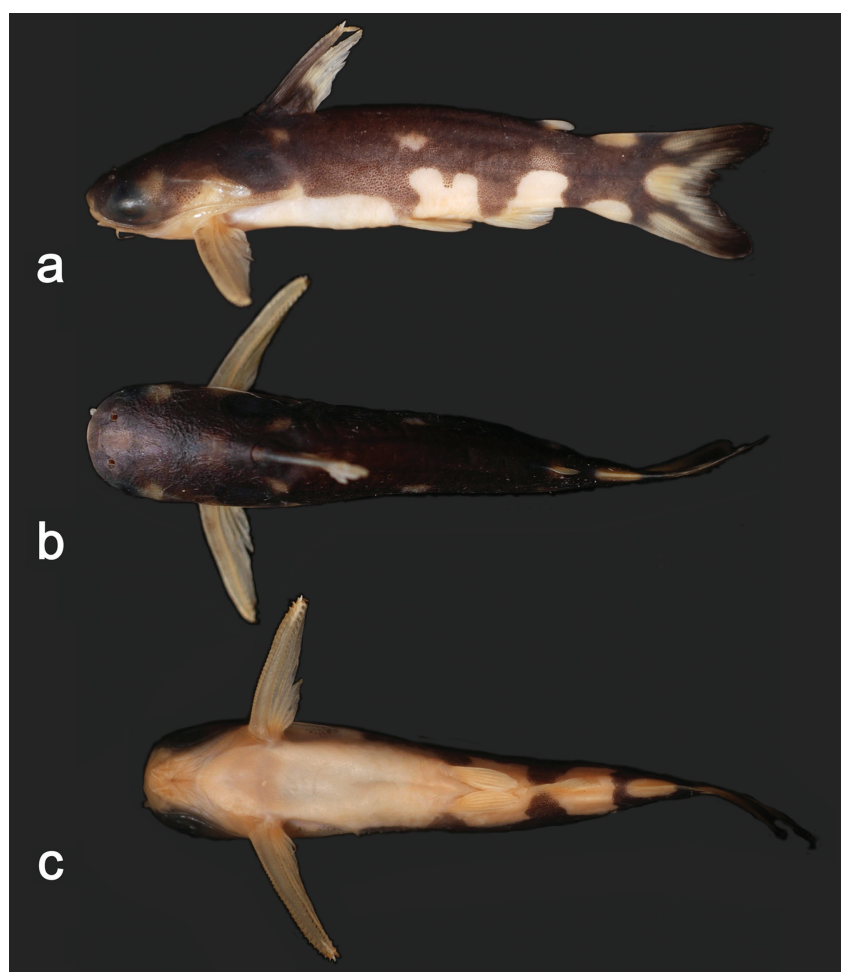

Fig. 1. Centromochlus orca, new species, holotype, INPA 50870, female, $56.8 \mathrm{~mm} \mathrm{SL}$, mouth of Igarapé Jamari with lago de Terra Santa, rio Nhamundá basin, middle Amazonas basin, Pará State, Brazil. Lateral (a), dorsal (b) and ventral (c) views. 
Holotype. INPA 50870, 1, 56.8 mm SL, Brazil, Pará, Terra Santa, mouth of Igarapé Jamari with lago de Terra Santa, rio Nhamundá basin, $02^{\circ} 00^{\prime} 04$ 'S 56³1'08'W, 22 Sep. 2009, R. P. Leitão \& H. Lazzarotto.

Paratypes. All from Brazil. Pará: Terra Santa: INPA 35086, $14+1 \mathrm{CS}, 40.5-56.8 \mathrm{~mm}$ SL, INPA 35087, 4, 21.0- 47.7 $\mathrm{mm}$ SL, MBML 11220, 1, $51.0 \mathrm{~mm}$ SL, MBML 11221, 1 CS, $50.6 \mathrm{~mm}$ SL, MNRJ 45072, 5+1 CS, 38.2-52.3 mm SL, MPEG 33927, 3, 39.0-50.8 mm SL, MZUEL 15706, 1, 42.8 mm SL, collected with the holotype. Amazonas: Nhamundá: INPA 43875, 4, 42.7-53.8 mm SL, lagoa Sete Ilhas upstream from Nhamundá, $01^{\circ} 50^{\prime} 28^{\prime}$ 'S $57^{\circ} 04$ '20"W, 12 Nov. 2013, R. A. Collins. INPA 43883, 3, 37.0-48.1 mm SL, Lagoa Sete Ilhas upstream from Nhamundá, on boundary between

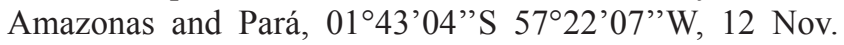
2013, R. A. Collins.

Non-type material. Brazil. Amazonas. Presidente Figueiredo: MZUEL 10467, 11, 25.7-46.2 mm SL, rio Uatumã, near mouth of rio Pitinga, at base WABA of ReBio Uatumã, in the reservoir of UHE, 01'31'19.7'S 6949'17.9”'W, 18 Sep. 2014, J. L. O. Birindelli, F. C. Jerep, L. Rapp Py-Daniel \& V. N. Machado.

Diagnosis. Centromochlus orca is distinguished from all congeners by its unique color pattern, black ground color sharply delimited from a white underside by conspicuous wavy border. Additional features for recognition of C. orca include the absence of anterior nuchal plate (Fig. 2) and eye diameter large, between 24.4 to $29.9 \%$ in HL.

The boldly contrasted black and white color pattern is unique to C. orca, but a similar pattern is found in T. musaica, from rio Orinoco, T. carolae Vari \& Ferraris 2013, from rio Cuyuni, lower Essequibo, and T. melanoleuca, from rio Teles Pires, upper Tapajós. All those species lack the anterior nuchal plate. Centromochlus orca is distinguished from T. musaica by coloration, as in C. orca the pattern is contrasted with white areas extending dorsally onto lower sides of body ( $v s$. a non-pigmented area in a mosaic pattern - compare Figs. 1 and 11). Notable differences among C. orca and T. musaica are observed in suspensorium bones (compare Figs. 3a and 3b), with contact between metapterygoid and quadrate via suture and cartilage (vs. contact between metapterygoid and quadrate via cartilage only in T. musaica), and hyomandibula broad, with a well developed medial lamina (vs. hyomandibula notched, lacking medial lamina in T. musaica). The color pattern in C. orca is contrasting as black and white colors, differing from the faint coloration in T. carolae and T. melanoleuca (see Vari \& Calegari, 2014, fig. 1; Vari \& Ferraris, 2013, fig. 1). Centromochlus orca is further distinguished from both T. melanoleuca and T. carolae by shape of Müllerian ramus disc (bulbous in $C$. orca vs. spoon shaped in $T$. melanoleuca and T. carolae) (compare Figs. 4a and 4b). For further details, see discussion.

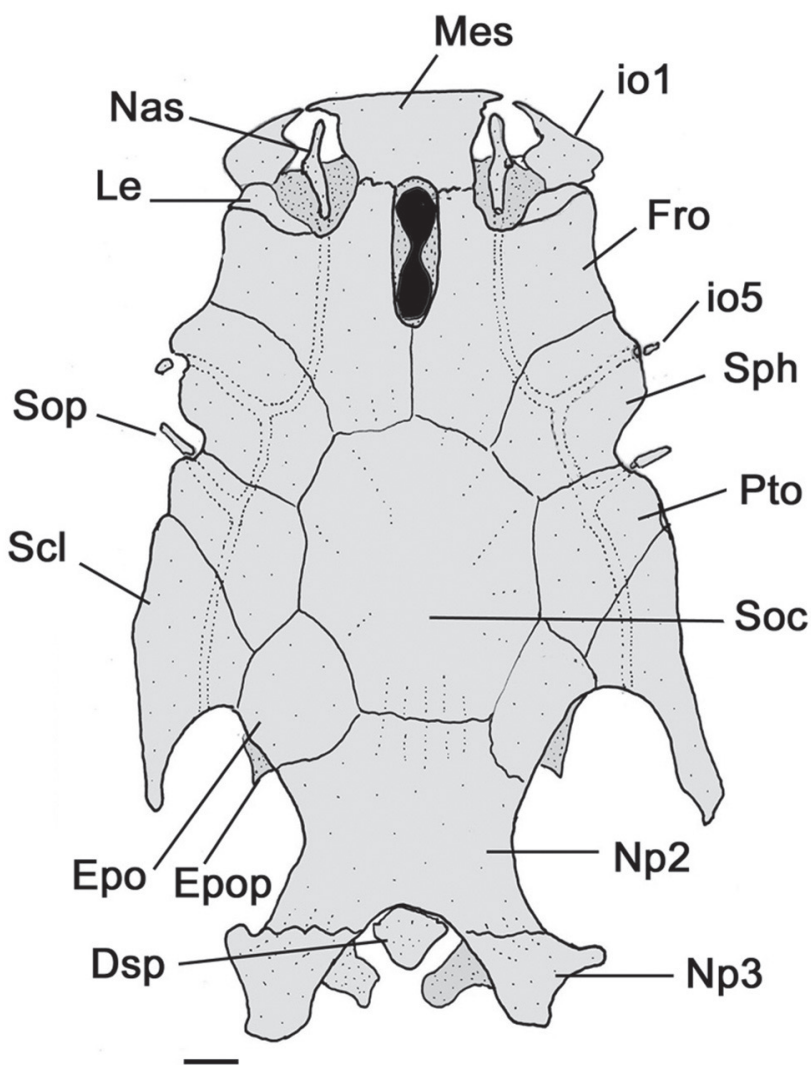

Fig. 2. Neurocranium of Centromochlus orca, INPA 35086, paratype, $54.1 \mathrm{~mm} \mathrm{SL}$. Dorsal view. Abbreviations: Dsp, dorsal fin spinelet; Epo, epiotic; Epop, epiotic process; Fro, frontal; io1, first infraorbital; io5, posterior ossified infraorbital; Le, lateral ethmoid; Mes, mesethmoid; Nas, nasal; Np2, middle nuchal plate; Np3, posterior nuchal plate; Pto, pterotic; Scl, posttemporal-supracleitrum; Soc, parieto-supraoccipital; Sop, suprapreopercle; Sph, sphenotic. Scale bar $=1 \mathrm{~mm}$.

Description. Morphometric data presented in Table 1. Small size, adult specimens 47.7-56.8 mm SL. Body almost cylindrical from rear of head through abdomen and gradually compressed towards caudal fin. Dorsal profile slightly convex from snout tip to dorsal-fin origin, approximately straight from that point to vertical through pelvic-fin origin, slightly convex to adipose-fin terminus, then slightly concave on caudal peduncle. Greatest body width at pectoral-fin origin, 19.4-22.1\% SL. Ventral profile of body gently concave between anal-fin base and caudal-fin origin. Greatest body depth at origin of dorsal fin, 17.3-20.8\%SL. Head integument thick, obscuring bones of cranial roof; eyes large, laterodorsal on anterior portion of head, covered by thick layer of translucent skin. Snout margin broadly rounded in dorsal view; anterior nostril close to snout margin, with tubular skin flap anteriorly oriented; posterior nostril also with tubular skin flap, located at vertical through anterior border of orbit; transverse distance between anterior nostrils almost equal to distance between posterior ones. Three pairs of 
barbels: maxillary, inner and outer mental. Maxillary barbel short, surpassing membranous border of opercle, reaching approximately vertical through dorsal-fin origin; adpressed maxillary barbel fits in groove on lateral portion of head, immediately above rictal fold and below eye; mental barbels short, tips not reaching pectoral-fin base; barbels arranged in arc along ventral surface of jaw; inner mental barbel about half the length of outer one. When adpressed, inner and outer mental barbels received by groove in skin. Posterior process of cleithrum moderately large, almost reaching vertical through middle of dorsalfin base.

Table 1. Morphometric data for Centromochlus orca. $\mathrm{SD}=$ Standard deviation, $\mathrm{N}=$ Number of specimens.

\begin{tabular}{|c|c|c|c|c|c|}
\hline & Holotype & Range & Mean & SD & $\mathrm{N}$ \\
\hline Standard length & 56.8 & $47.6-56.8$ & 51.5 & 3.4 & 13 \\
\hline \multicolumn{6}{|c|}{ Percent of standard length } \\
\hline Body depth & 18.8 & $17.5-20.8$ & 19.2 & 0.9 & 13 \\
\hline Body width & 12.9 & $18.9-22.3$ & 20.8 & 1.2 & 13 \\
\hline Caudal-peduncle depth & 19.9 & $9.9-12.9$ & 11.2 & 0.8 & 13 \\
\hline Caudal-peduncle length & 22.9 & $19.3-26.5$ & 23.7 & 2.2 & 13 \\
\hline Predorsal length & 34.7 & $32.8-37.8$ & 35.0 & 1.6 & 13 \\
\hline Preanal length & 68.7 & $67.8-72.2$ & 69.7 & 1.3 & 11 \\
\hline Prepelvic length & 56.5 & $52.7-56.9$ & 55.1 & 1.9 & 13 \\
\hline Dorsal to pectoral origin & 24.6 & $20.7-24.8$ & 23.8 & 1.1 & 13 \\
\hline Dorsal to pelvic origin & 31.5 & $27.9-34.3$ & 30.9 & 1.8 & 13 \\
\hline Pectoral to pelvic origin & 36.6 & $33.8-38.3$ & 36.3 & 1.2 & 13 \\
\hline Prepectoral length & 22.0 & $20.0-26.8$ & 22.7 & 1.7 & 13 \\
\hline Dorsal-fin base length & 12.5 & $11.1-12.9$ & 12.0 & 0.6 & 13 \\
\hline Adipose-fin base length & 2.7 & $2.7-5.1$ & 3.7 & 0.8 & 12 \\
\hline Anal-fin base length & 7.7 & $6.1-8.8$ & 7.8 & 0.9 & 11 \\
\hline Dorsal-fin spine length & 22.2 & $20.1-24.2$ & 22.2 & 1.3 & 11 \\
\hline Pectoral-fin spine length & 27.5 & $25.2-31.1$ & 28.0 & 1.7 & 12 \\
\hline Posterior process of cleithrum length & 21.3 & $19.8-24.6$ & 22.1 & 1.4 & 13 \\
\hline First branched pelvic-fin ray length & 12.9 & $11.8-14.0$ & 12.8 & 0.7 & 13 \\
\hline Longest anal-fin ray & 11.4 & $11.1-12.6$ & 11.7 & 0.5 & 11 \\
\hline Maxillary-barbel length & 34.0 & 28.7-37.6 & 32.9 & 2.8 & 12 \\
\hline Outer mental-barbel length & 7.7 & $5.2-11.7$ & 8.2 & 1.9 & 12 \\
\hline Inner mental-barbel length & 3.7 & $3.5-7.2$ & 4.8 & 1.4 & 12 \\
\hline Head length & 25.9 & $24.8-29.2$ & 26.7 & 1.5 & 13 \\
\hline \multicolumn{6}{|c|}{ Percent of head length } \\
\hline Head width & 74.8 & $70.6-77.3$ & 75.3 & 1.8 & 13 \\
\hline Head depth & 46.3 & $42-49.1$ & 45.8 & 2.8 & 13 \\
\hline Interorbital distance & 57.8 & $53.1-60.3$ & 57.7 & 2.4 & 13 \\
\hline Left internarial distance & 25.9 & $20.3-28.7$ & 23.3 & 2.7 & 13 \\
\hline Anterior internarial distance & 34.7 & $31.5-37.0$ & 34.5 & 1.5 & 13 \\
\hline Posterior internarial distance & 32.0 & $31.5-37.0$ & 34.1 & 2.0 & 13 \\
\hline Snout length & 33.3 & $29.1-36.0$ & 32.7 & 2.4 & 13 \\
\hline Orbital diameter & 24.5 & 24.4-29.9 & 26.6 & 2.0 & 13 \\
\hline Mouth width & 34.7 & $26.4-34.8$ & 31.6 & 2.9 & 13 \\
\hline
\end{tabular}

Rostral border of cranium with mesethmoid broader than long; premaxilla with synchondral articulation; cranial fontanel narrow and elliptical, enclosed by mesethmoid and frontals (Fig. 2). Nasal ossified as short tubular bone situated between mesethmoid cornua and lateral ethmoid, not sutured to mesethmoid. Lateral ethmoid not participating in dorsal face of cephalic shield. Autopalatine rod-like, oriented almost parallel to longitudinal axis of body; maxilla slightly elongated, about two-thirds the size of autopalatine (Fig. 3, mx); vomer arrow-shaped with short rostral-lateral processes. Jaws of equal size; premaxilla and dentary slender, each with two or three rows of small conical teeth. Anterior nuchal plate absent; middle nuchal plate slightly concave along lateral margins; posterior nuchal plate short, projected laterally, with prominent tip. Epioccipital process small.

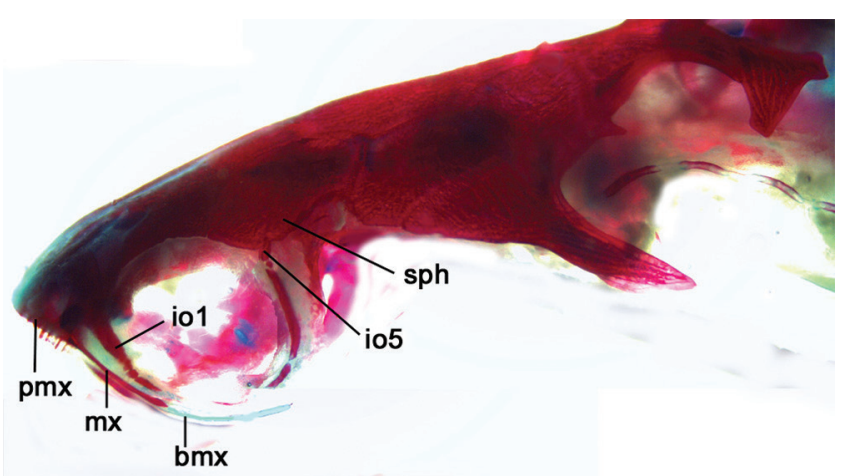

Fig. 3. Head in lateral view of a cleared and stained specimen of Centromochlus orca, MBML 11221, 50.6 $\mathrm{mm}$ SL. Photo by L. Sarmento-Soares. Abbreviations: bmx, maxillary barbel; io1, first infraorbital; io5, posterior ossified infraorbital; mx, maxilla; pmx, premaxilla; sph, sphenotic.

Hyomandibular broad, with anteriorly projected lamina, connected to quadrate only, through cartilage and deeply interdigitated suture (Fig. 4a, hm). Quadrate large, trapezoidal, with broad base, sutured to preopercle, hyomandibular and metapterygoid. Metapterygoid somewhat rectangular, as short lamina, joined to quadrate via suture (Fig. 4a, mt); entopterygoid in connective tissue linking metapterygoid to lateral process of vomer (Fig. $4 \mathrm{a}$, en). Long ventral margin of preopercle sutured to both quadrate and hyomandibula; suprapreopercle present as long canal bone; preopercular canal exiting on anterior portion of pterotic. Opercle laminate, ornamented and broadly subtriangular.

Hyoid arch with compact parurohyal with short ventral process; short dorsal hypohyal associated with comparatively large ventral hypohyal (Fig. 6, vh); anterior ceratohyal more developed than posterior ceratohyal. Six branchiostegal rays articulated with hyoid arch, four slender rays associated with anterior ceratohyal, two flattened rays with posterior ceratohyal (Fig. 6, br). Branchiostegal membrane broadly united to isthmus. 

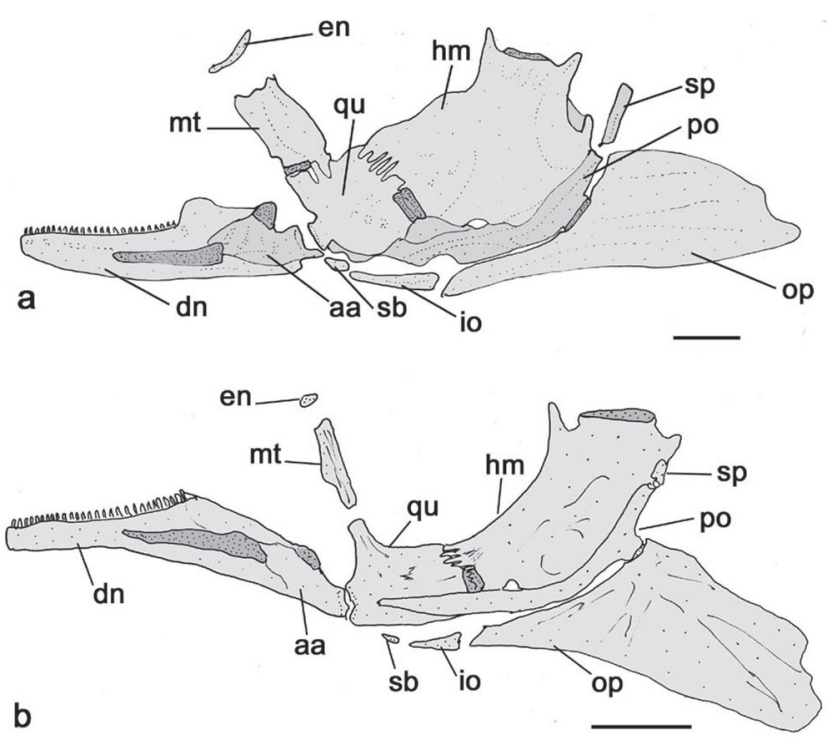

Fig. 4. Right suspensorium, lateral view, of a. Centromochlus orca, INPA 35086, paratype, $54.1 \mathrm{~mm}$ SL. b. Tatia musaica, MBUCV-V 17727, paratype, $24.3 \mathrm{~mm}$ SL. Abbreviations: aa, angulo-articular; dn, dentary; hm, hyomandibula; io, interopercle; mt, metapterygoid; en, endopterygoid; op, opercle; po, preopercle; qu, quadrate; sb, subpreopercle; sp, suprapreopercle. Scale bar $=1 \mathrm{~mm}$.

Branchial (gill) arches with urohyal close to basibranchial 2; basibranchial 2 mostly cartilaginous, broadest anteriorly, slightly separated from basibranchial 3 (Fig. 7, bb2); basibranchial 3 shorter, forming osseous rod; basibranchial 4 large, flattened and cartilaginous; basibranchial 2 bordered laterally by cartilaginous head of hypobranchial 1; basibranchial 3 between cartilaginous head of hypobranchial 2 and cartilaginous hypobranchial 3 ; basibranchial 4 bordered laterally by cartilaginous head of ceratobranchial 4 and caudally by cartilaginous head of ceratobranchial 5. Hypobranchials 1 and 2 subtriangular, mostly osseous, elongate and expanded laterally, with cartilaginous tips (Fig. 7, hb1, hb2); hypobranchial 3 mainly cartilaginous, trapezoidal; hypobranchial 4 absent. Five ceratobranchials, mostly ossified, with cartilage on both tips (Fig. 7, cb1-5). Ceratobranchials supporting single row of rakers; fifth ceratobranchial expanded postero-medially to support lower pharyngeal toothplate bearing short conical teeth. Four epibranchials, all largely ossified except for cartilaginous tips, each one supporting few rakers, close to articulation with ceratobranchials. Epibranchials 1 and 2 rod-like; epibranchial 3 with posterior uncinate process articulated to epibranchial 4; epibranchial 4 with laminar extension; reduced accessory cartilage located at angle between cartilaginous tips of epibranchial 4 and ceratobranchial 4. Pharyngobranchial 1 absent; pharyngobranchial 2 short, cartilaginous, somewhat ellipsoid, placed between anteromedial cartilaginous tips of epibranchials 1 and 2; pharyngobranchial 3 elongate, ossified, with expanded posterior border; pharyngobranchial 4 ossified. Upper pharyngeal tooth plate bearing conical teeth, supported by pharyngobranchial 3 and 4, and also epibranchials 3 and 4 (Fig. 7, fb3, fb4).

Müllerian ramus disc of parapophysis of fourth vertebrae with enlarged tip forming bulbous projection, directed posteriorly, extending into lumen of swim bladder (Fig. 5a, pv4).

Laterosensory cephalic canal with infraorbital 1 bearing a ventrolateral process restricted to anterior border of eye, and followed by four canal-like bones, in incomplete infraorbital series. Dorsal rim of orbit formed mainly by frontal, with sphenotic contributing the posteriormost limit. Infraorbital canal exiting on middle portion of sphenotic. Lateral line weakly sinuous and with ossified canal bones on anteriormost portion of trunk, then approximately straight with singular terminus on base of caudal-fin rays.

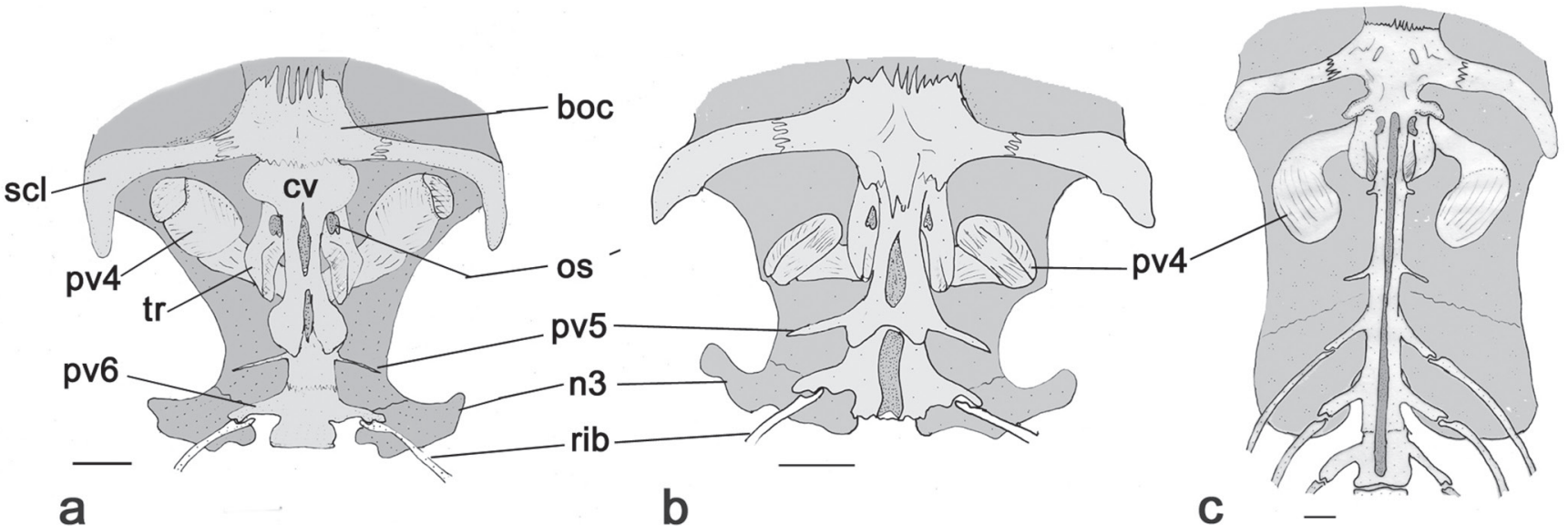

Fig. 5. Anterior vertebrae and associated bones, ventral view, of a. Centromochlus orca, INPA 35086, paratype, $54.1 \mathrm{~mm}$ SL. b. Tatia melanoleuca, MZUSP 30585, $53.0 \mathrm{~mm}$ SL. c. Centromochlus heckelii, MZUSP 8336, $62.0 \mathrm{~mm}$ SL. Abbreviations: n3, posterior nuchal plate, boc, basioccipital, cv, complex vertebra, Pv4, parapophysis of fourth vertebra, Pv5, parapophysis of fifth vertebra, Pv6, parapophysis of sixth vertebra, os, os suspensorium, rib, precaudal rib, scl, trans-scapular process of posttemporal-supracleithrum, tr, tripus. Scale bar $=1 \mathrm{~mm}$. 


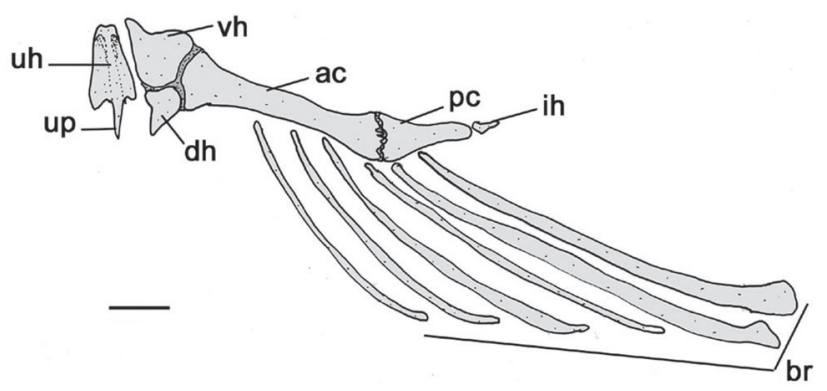

Fig. 6. Right hyoid arch of Centromochlus orca, INPA 35086, paratype, $54.1 \mathrm{~mm} \mathrm{SL}$. Ventral view. Abbreviations: ac, anterior ceratohyal; br, branchiostegal rays; dh, dorsal hypohyal; ih, interhyal; pc, posterior ceratohyal; vh, ventral hypohyal; uh, urohyal; up, urohyal ventral process. Scale bar $=1 \mathrm{~mm}$.

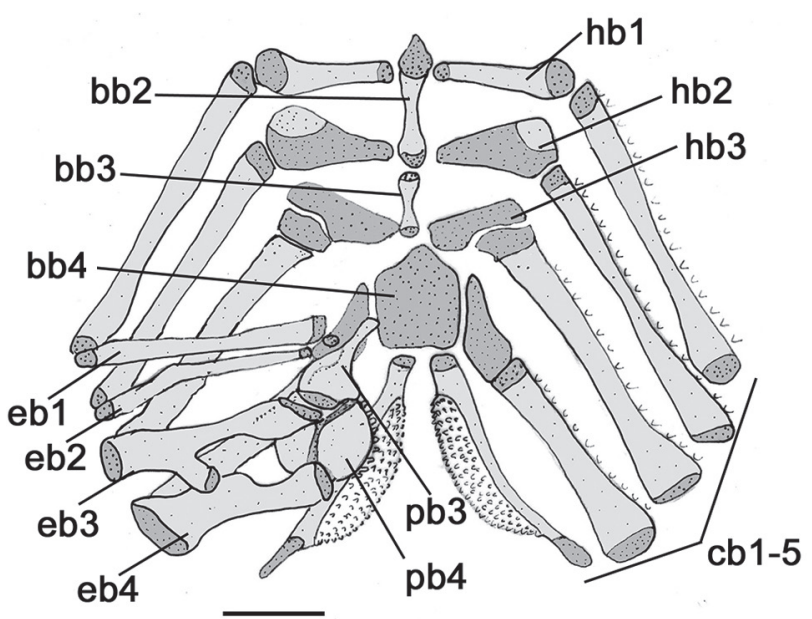

Fig. 7. Pharyngeal arches of Centromochlus orca, INPA 35086, paratype, $54.1 \mathrm{~mm}$ SL. Dorsal view. Abbreviations: bb2-4, basibranchials 2 to 4 (anterior to posterior); cb15, ceratobranchials 1 to 5 (anterior to posterior); eb14, epibranchials 1 to 4 (anterior to posterior); hb1-3, hypobranchials 1 to 3; pb3, pharingobranchial 3; pb4, pharingobranchial 4 . Scale bar $=1 \mathrm{~mm}$.

Dorsal fin II,5; dorsal-fin spine strong, slightly shorter than first branched ray, anterior face with about 20 minute dentations becoming progressively smaller towards fin base; posterior face mostly smooth except for 3-8 retrorse dentations distally; fin tip cartilaginous. Pectoral fin I,5. Pectoral-fin spine strong with 25-33 antrorse dentations on anterior face; 20-22 retrorse dentations on posterior face; dentations on both faces become larger towards tip. Pelvic fin i,5, lateral margin rounded. Adipose fin teardrop shaped, with free posterior margin. Anal fin iii,7; anal-fin pterygiophores with eight rod-like proximal radials and six cartilaginous distal radials. Caudal fin moderately forked, lobes with rounded tips, $8+9$ principal rays, all rays branched except for outermost ray of upper and lower lobes; 20-22 upper and 17-19 lower procurrent rays.

Nine ribs attached to consecutive vertebrae 6-14, becoming progressively smaller posteriorly. Total vertebrae 30 (observed in three cleared and stained specimens).
Coloration in alcohol. Centromochlus orca has unique color pattern, black ground color sharply delimited from white underside by conspicuous wavy border through lower half of body side. Dorsal cloak uniformly dark or sometimes with white rounded blotch in larger specimens, rounded extensions of dark coloration reach the base of both anal and pelvic fins. Dorsal surface of head also largely black, with tips of third nuchal plate whitish-brown. Latero-ventral sides and belly whitish-yellow, strongly contrasting dark cloak. Posterior process of cleithrum pale to mostly black. Paired and anal fins whitish-yellow with hyaline tips. Dorsal fin with dark base. Dorsal fin spine mostly dark, branched rays hyaline. Adipose fin with dark base and hyaline tips. Caudal peduncle with white half-circle on upper and lower margins. Caudal fin with white circle on fin base; each lobe with pale outer streak and broader dark inner stripe (Fig. 8).

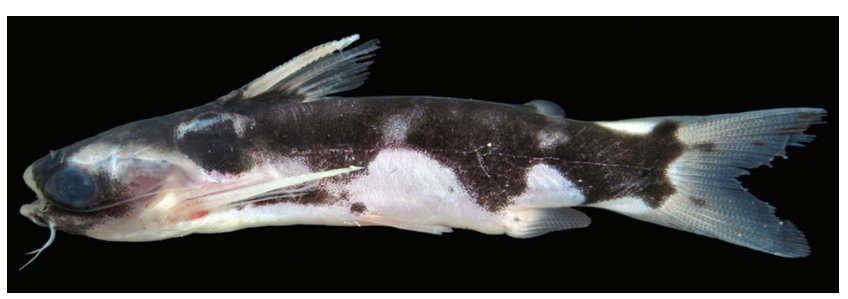

Fig. 8. Centromochlus orca, MZUEL 10467, $44.8 \mathrm{~mm}$ SL, adult male, showing modified anal fin. Photo by J. L. Birindelli.

Live coloration. Bold pattern of black and white more highly contrasted than in preserved specimens. Dorsal and lateral surfaces of head with distinctive dark coloration; translucent areas on tip of snout, posterior nuchal plate region, and opercular area. Dark cloak with light rounded blotch present on each side of body between dorsal and adipose fins in large specimens. Belly, anal and paired fins white with traces of pink. Dorsal and pectoral fin spines dark. Adipose fin with dark base and yellow tip. Half circles on caudal peduncle, rounded blotch on caudal-fin base and outer streak on each lobe light-yellow (Fig. 9).

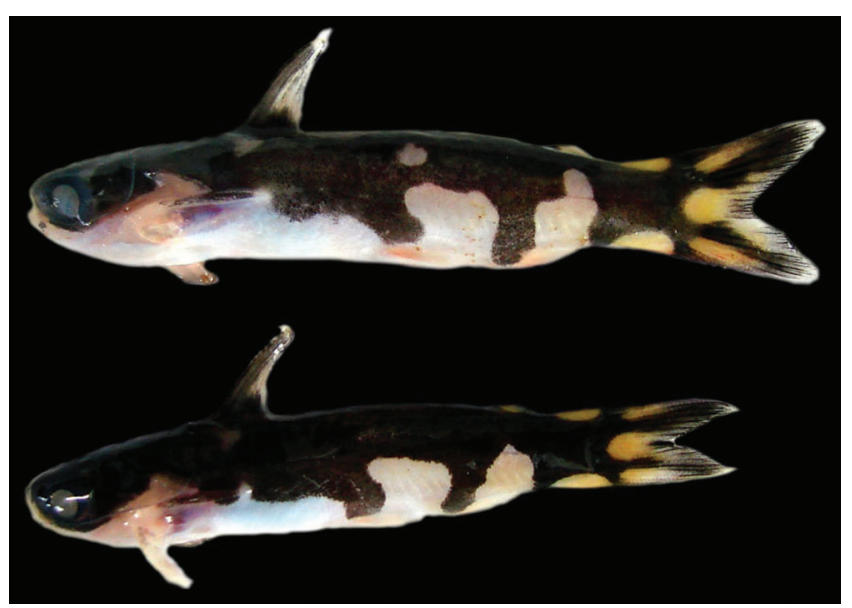

Fig. 9. Centromochlus orca, new species, just after capture. Photo by H. Lazzarotto. 
Distribution. Centromochlus orca is known from the mouth of igarapé Jamari, a tributary of the lower rio Nhamundá, in the western Pará, and from two close localities in lagoa Sete Ilhas upstream from Nhamundá, on boundary between Amazonas and Pará, in a region along the transition between the Amazonas floodplain and the Guiana Shield (Fig. 10).

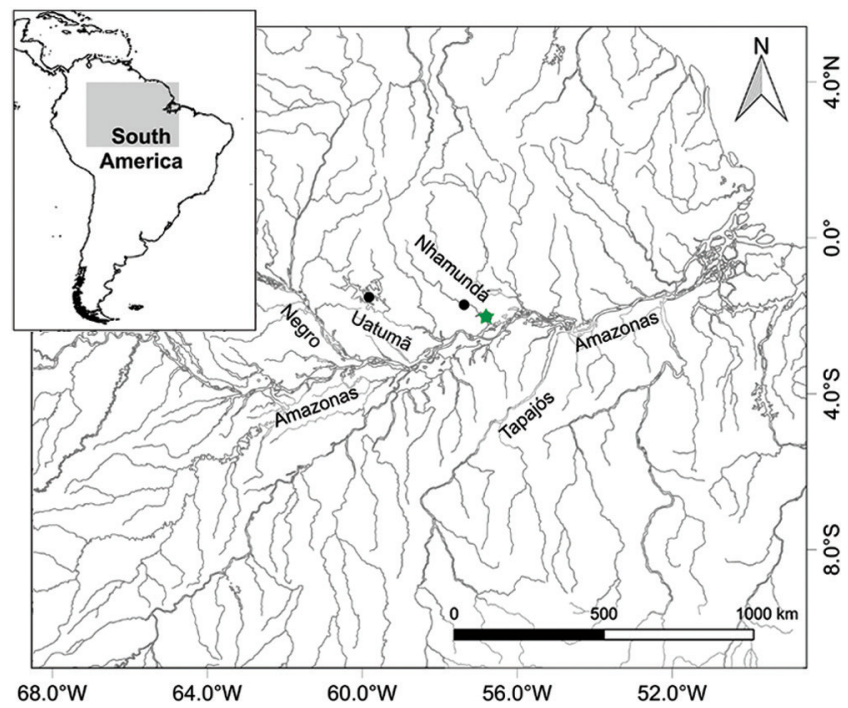

Fig. 10. Distribution of Centromochlus orca. Green star represents type locality.

Ecological notes. In the rio Nhamundá basin, the specimens of $C$. orca were collected in the lower portions of igarapé Jamari, in the transition zone between lotic river habitats and lentic habitats of varzea lakes (Fig. 11). In igarapé Jamari, the water current was virtually absent. Individuals of $C$. orca were observed actively swimming on the surface or in mid-column in places illuminated by light bulbs close to the shoreline or on boats. All specimens were collected during the night, either by seining (a sandy beach) or with dip nets while swimming (in illuminated areas). Fish assemblages at these localities are highly diverse, encompassing species mainly from the white-water floodplains, but including some taxa typical of clear water rivers that flow from the Guiana Shield, such as Hoplarchus psittacus, Hypancistrus sp., Otocinclus mura and Peckoltia vittata. Among the other 151 species collected syntopically with $C$. orca, Tatia nigra was the only additional Centromochlinae. Local fishermen reported that $C$. orca is caught and sold for the aquarium trade, but is not a primary target.

Sexual dimorphism. Among all specimens examined, none have a fully modified anal fin for insemination. One maturing male exhibited partial modified anal fin (Fig. 8).

Etymology. The specific epithet is an allusion to the coloration resembling that of the orca whales (Orcinus orca). A noun in apposition.
Conservation status. Centromochlus orca was recorded for lower portions of rio Nhamundá basin at western Pará, near border with Amazonas state. It corresponds to an species of small fish, with pelagic habits and apparently non migratory. Although reports of specimens caught for aquarium trade, such an activity do not represent a primary target, and possibily does not cause a severe impact in fish natural populations. The species is abundant in the places where it is found and no significative threatening were recognized for the species locally. Centromochlus orca was categorized as Least Concern (LC), according to the IUCN criteria for evaluation on threatening status (IUCN, 2016).

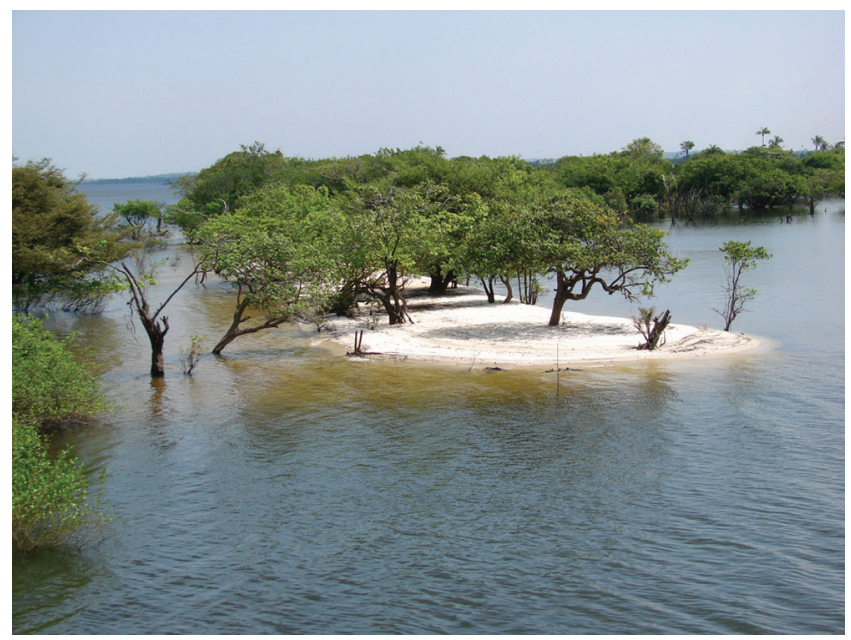

Fig. 11. Igarapé Jamari, type locality of Centromochlus orca, rio Nhamundá basin, middle Amazonas basin, municipality of Terra Santa, Pará State, Brazil. Photo by H. Lazzarotto.

\section{Discussion}

Centromochlus orca is promptly distinguished from type species C. heckelii and from C. existimatus, C. macracanthus by having shorter dorsal-fin spine $(20-24 \%$ vs. $29-35 \%$ in $\mathrm{SL})$. Further differs from C. existimatus and C. heckelii, by having six or seven ( $v s .5)$ branched anal-fin rays and by the bulbous shape of disc portion, the Müllerian ramus, of parapophysis of fourth vertebrae (vs. disc portion elongated, Fig. 5c). Unlike C. existimatus, C. heckelii, C. altae Fowler 1945 and C. perugiae Steindachner 1883, C. orca lacks an anterior nuchal plate.

Eleven other species of Centromochlus share the absence of anterior nuchal plate: $C$. meridionalis Sarmento-Soares et al. 2013, C. romani Mees 1988, C. ferrarisi Birindelli et al. 2015, C. britskii Sarmento-Soares \& Birindelli 2015, C. punctatus (Mees 1974), C. bockmanni (Sarmento-Soares \& Buckup 2005), C. concolor (Mees 1974), C. simplex (Mees 1974), C. reticulatus (Mees 1974), C. schultzi Rössel 1962, and C. macracanthus. Centromochlus orca differs from C. meridionalis and $C$. romani by having dentations on the anterior face of dorsalfin spines (vs. absent). From C. ferrarisi and C. britskii by having posterior margin of dorsal-fin spine with dentations 
(vs. smooth); from C. punctatus by the long posterior process of cleithrum, length $20.1-23.6 \%$ in SL (vs. short, 9.5-13.8 \% in SL). From C. bockmanni, C. concolor, C. simplex, and C. reticulatus, C. orca differs by the parapophysis of fourth vertebra, with a particular shape of Müllerian ramus disc posteriorly elongated, slightly extending into lumen of swim bladder ( $v s$. Müllerian ramus disc flat, spoon shaped, superficially contacting swim bladder wall only).

Although lacking anterior nuchal plate, C. orca is distinguished from Gelanoglanis by straight mouth gape, not reaching vertical through eye (vs. sinuous, large mouth gape, trespassing vertical through eye); posterior nare opening small, about same size of anterior one ( $v s$. posterior nare opening large, about three times in anterior one); eye size more than $20 \%$ in HL ( $v s$. reductive eyes, less than $10 \%$ in HL); two pairs of chin barbels ( $v s$. one pair); rostral margin of mesethmoid straight (vs. curved); vomer present (vs. absent); nasal channel passing through an ossified nasal bone ( $v s$. nasal channel free, no ossified bone present); lateral line straight (vs. sinuous at least anteriorly); infraorbital canal of cephalic laterosensory system involved in infraorbital ossicles (vs. canal free, no ossicles present); mandibular ramus of cephalic laterosensory system within dentary bone ( $v s$. free from dentary); premaxillary tooth patches in contact at mesial margin of upper jaw (vs. widely separated anteriorly at midline); coronoid process of mandibula straight ( $v s$. hook shaped); Müllerian ramus disc of $4^{\text {th }}$ parapophysis produced posterior ( $v s$. flat, reduced to a small spoon shape).

Centromochlus orca differs from remaining centromochlin catfishes in Glanidium and most Tatia, except Tatia melanoleuca, T. carolae and T. musaica by lacking anterior nuchal plate ( $v s$. presence).

Britski (1972) provided the first revision of the auchenipterid catfishes largely based on anatomical features. He noticed that in Centromochlus heckelii the parapophysis of fourth vertebrae constituted by a peduncle plus a rounded disc (called Müllerian ramus) formed a bulbous projection into the swim bladder, like a finger into a glove. Latter, this feature was also observed in $C$. existimatus (Soares-Porto, 1998). The vertebrae 1-5 is largely modified into the Weberian complex. In most Doradoidea catfishes, the distal tip of the transverse process of fourth vertebrae, referred as Müllerian ramus by Tavolga (1962), is expanded and broadly contacts the anterior end of swim bladder (Ferraris, 1988). There is considerable variation in the form of Müllerian ramus disc, along with the derivation of associated muscular attachments (Ferraris, 1988). If a gradual variation do exist among species, it remains to be fully investigated. Centromochlus orca specimens have a distinctive axial skeleton, with intermediate condition regarding a bulbous Müllerian ramus disc, in which the distal tip of process is elongated (Fig. 7a). The same condition is observed in specimens of Tatia musaica, and in both species it is intermediate between that of $C$. heckelii and $C$. existimatus, in which the Müllerian ramus disc is much elongated, projecting deep into lumen of swim bladder (Fig. 7, pv4). In the remaining Centromochlus species the Müllerian ramus is a flattened disc, spoon shaped, resting on the anterior surface of the swim bladder (Fig. 7b). The enlarged tip of Müllerian ramus forming a bulbous projection is unique to $C$. orca and T. musaica and questions their placement in different genera. The coloration of $C$. orca resembles that of $T$. musaica, leading to the misidentification of Amazonian specimens as T. musaica (compare Figs. 1 and 12).

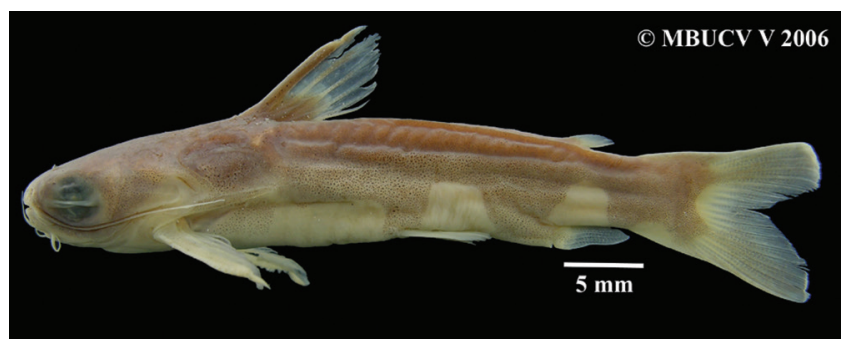

Fig. 12. Tatia musaica, MBUCV V-15663, 47.1 mm SL, morphologically similar centromochlin species from the Guiana Shield in Amazonas, Venezuela. Photo by C. DoNascimiento and N. Milani. Copyright(C F. Provenzano and Museo de Biologia de la Universidad Central de Venezuela. Available at http://acsi.acnatsci.org/

Tatia musaica was originally described in Tatia (Royero, 1992), removed to incertae sedis in Centromochlinae by Sarmento-Soares \& Martins-Pinheiro (2008) and recently re-assigned to Tatia by Vari \& Ferraris (2013). An assignment of $T$. musaica to Tatia was justified on the basis of caudal peduncle depth greater than $10 \% \mathrm{SL}$, a condition that agrees with the diagnosis of Tatia (Vari \& Ferraris, 2013: 401). Examination of material of $T$. musaica, including types, revealed that it has features that fit both in Tatia, such as an intermediate caudal peduncle depth, 7.7-12\% in SL, and a deeply notched hyomandibula; and Centromochlus, such as elongate maxilla that extends into the maxillary barbel, anterior nuchal plate absent and ventrolateral process of infraorbital 1 forming the anterior border of orbital rim. Regarding the dubious position of T. musaica within available genera of Centromochlinae, a reappraisal of phylogenetic relationships within the subfamily is in preparation (LMSS). Based on this ongoing study of centromochlin catfishes, there is some evidence that $T$. musaica and $C$. orca are sister species in a more inclusive Centromochlus clade. In this paper we retain $T$. musaica in Tatia to avoid confusion, but consider Tatia to be a paraphyletic assemblage.

Centromochlus orca shares with some Tatia species a moderately deep caudal peduncle, 10.4 to $11.8 \%$ in SL, a condition found in T. caxiuanensis Sarmento-Soares \& Martins-Pinheiro 2008, T. gyrina (Eigenmann \& Allen 1942), T. meesi Sarmento-Soares \& Martins-Pinheiro 
2008, T. melanoleuca Vari \& Calegari 2014 and T. musaica Royero 1992, species with caudal peduncle depth ranging between $9.6-12 \%$ in SL ( $v s$. between $14-19 \%$ in remaining Tatia).

We herein assume T. melanoleuca as distributed along rio Tapajós, in accordance to rio Jamanxim image reports (Vari \& Calegari, 2014) and upon examination of additional material. Regarding the recently described $T$. carolae, $C$. orca is distinguished by its diagnostic black ground color sharply delimited from a white underside by conspicuous wavy border ( $v s$. demarcation between dark pigmentation faint delimited from white sides nearly to the ventral midline - Vari \& Ferraris, 2013, fig. 1). Tatia carolae is much similar to T. musaica regarding color pattern, and both species are possibly closely related to C. orca.

In addition to features of color pattern, Centromochlus orca and T. musaica share large eyes (about 26-30\% in $\mathrm{HL}$ ), long maxilla slightly extending into barbel, and dorsal and pectoral fin spines moderately long (20-30\% in SL); absence of anterior nuchal plate, and bulbous Müllerian ramus disc (Fig. 7a).

In spite of the similarities with some Tatia, the new species is undoubtedly a member of Centromochlus due to having maxillary ossification long, penetrating about one third of barbel length (Fig. 3); an elongate ventrolateral process of infraorbital 1, forming anterior border of orbit and a sharp crest forming keel on parasphenoid for attachment of the adductor arcus palatini, features hypothesized as derived for genus (Soares-Porto, 1998; Sarmento-Soares \& Porto, 2006).

The distributions of both $C$. orca and T. musaica appears to be disjunct. Tatia musaica is distributed in the Guiana shield, in tributaries of upper rio Orinoco basin between border of Venezuela and Colombia, and in Roraima, Brazil, in the upper rio Branco, a tributary in the rio Amazonas basin (Royero, 1992; collection data). On the other hand, C. orca is found in lowlands at the transition zone between the Guiana Shield and Amazon floodplain in the rio Nhamundá, between Pará and Amazonas states. A notable aspect of the known distribution of Centromochlus orca is its apparently disjunct distribution in the rio Nhamundá (type locality) and rio Uatumã, on eastern Amazonas state. Historically, the rio Uatumã may have served as freshwater corridor between the Guiana Shield uplands and lowlands of the lower Amazon. The distributional limits of T. musaica, $C$. orca and many other species of Centromochlinae are not clearly understood and additional sampling is necessary to amplify our knowledge of their distributional patterns and historical biogeography.

Comparative material examined. Centromochlus altae. Colombia. USNM 121965, 1, $35.5 \mathrm{~mm}$ SL, río Dedo, tributary of río Orteguazo. Centromochlus bockmanni. Brazil. Bahia state. MZUSP 82351, 8, 1 CS, 29.4-35.8 mm SL, paratypes of
Glanidium bockmanni Sarmento-Soares \& Buckup, 2005, Rio Preto at Formosa do Rio Preto. Centromochlus britskii. Brazil. São Paulo State. MZUSP 115271, 39.2 mm SL, MZUSP 43251, 2, $1 \mathrm{CS}, 33.5-36.3 \mathrm{~mm}$ SL and MNRJ 41787, 2, 36.0-38.6 mm SL, paratypes of Centromochlus britskii Sarmento-Soares \& Birindelli, 2015, rio Paraná where is now the Ilha Solteira reservoir, upper rio Paraná basin. Centromochlus concolor. Surinam. ZMA 106210, 1, $33.4 \mathrm{~mm}$ SL, holotype of Tatia concolor Mees, 1974, Rx, ZMA 106209, 29.0-30.6 mm SL, paratype of Tatia concolor Mees, 1974, Rx, Coppename river. Centromochlus existimatus. Brazil. Acre State. MZUSP 48880, 1, $90.2 \mathrm{~mm}$ SL, Porto de rio Branco, rio Branco. Pará State. INPA 40662, 6, 46.5- $57.9 \mathrm{~mm} \mathrm{SL}$, public beach, right margin of rio Xingu, Porto de Moz. Centromochlus ferrarisi. Brazil. Tocantins State. MNRJ 41924, 1, $57.6 \mathrm{~mm}$ SL and MZUSP 115352, 2, 50.4$68.1 \mathrm{~mm} \mathrm{SL}, 1 \mathrm{CS}, 68.4 \mathrm{~mm} \mathrm{SL}$, paratypes of Centromochlus ferrarisi Birindelli, Sarmento-Soares \& Lima, 2015, Rio da Conceição, headwater of Rio das Balsas, Estação Ecológica Serra Geral do Tocantins. Centromochlus heckelii. Brazil. Acre State. MZUSP 48910, 2, 80.0-83.2 mm SL, rio Acre between seringal Paraíso and lagoa Amapá. Pará State. MZUSP 8336, 2 CS, 53,4$62,0 \mathrm{~mm}$ SL, rio Tapajós, Santarém. Amazonas State. INPA 8203, 2, 73.3-81.8 mm SL, Manacapuru. INPA 10967, 2, 106.2$108.7 \mathrm{~mm} \mathrm{SL}$, rio Jamari. INPA 8369, 5, 62.3- $74.0 \mathrm{~mm}$ SL, rio Amazonas, downstream from Paraná da Eva, Itacoatiara. INPA 12643, 6, 86.7- 90.5 mm SL, rio Jaú, Novo Airão. Centromochlus macracanthus. Brazil. Amazonas State. INPA 6565, 1, 129.7 $\mathrm{mm}$ SL, paratype of Centromochlus macracanthus Soares-Porto, 2000, rio Negro. INPA 43009, 6, 55.4- 71.9 mm SL, rio Negro, Cachoeira Curucui, São Gabriel da Cachoeira. MZUSP 30605, 2, 65.7-71.8 mm SL, paratypes of Centromochlus macracanthus Soares-Porto, 2000, rio Negro, Cachoeira de São Gabriel, São Gabriel da Cachoeira. Centromochlus meridionalis. Brazil. Mato Grosso State. MBML 5616, 1 CS, $39.1 \mathrm{~mm}$ SL, MBML 5617, 3, 32.2-46.2 mm SL and MNRJ 40702, 3, 32.6-38.3 mm SL, paratypes of Centromochlus meridionalis Sarmento-Soares, Cabeceira, Carvalho, Zuanon \& Akama, 2013, Córrego Loanda, a small tributary of rio Roquete, Cláudia. Centromochlus perugiae. Brazil. Acre State. MZUSP 31880, 1, $28.2 \mathrm{~mm} \mathrm{SL}, \mathrm{Rx}$, rio Tarauacá, Tarauacá. Ecuador. MNRJ 30489, 1, 38.5 mm SL, rio Aguari, Napo. Peru. MNRJ 30490, 1, 38.4 mm SL, Huanuco, Amazonas. MZUSP 26029, 2, 22.3-29.8 mm SL, rio Chiriaco, provincia Bagua. MZUSP 26684, 4, 26.2-35.9 mm SL, arroyo de Ivita-Pucallpa, Caserio Neshuya, Provincia Coronel Portillo, Ucayali. Centromochlus punctatus. Brazil. Pará State. RMNH. PISC 26494, 2, 33.3-43.2mm SL, paratypes of Tatia punctata Mees, 1974, Rx, Igarapé Kumadueni, tributary of Rio Paru. Suriname. RMNH 26496, 3, 36.2- $39.3 \mathrm{~mm}$ SL, paratypes of Tatia punctata Mees, 1974, Rx, rivers between Kabel and Lombé. Centromochlus reticulatus. Guyana. RMNH.PISC 26744, 2, 18.3-39.8 mm SL, paratypes of Tatia reticulata Mees, 1974, Rx, Karanambo, Rupununi. Centromochlus romani. Venezuela. AMNH 91382, 2, 32.5-32.7 mm SL, rio Siapa, Amazonas. INHS 27999, 1, $31.0 \mathrm{~mm}$ SL, rio Michay, Apure drainage, Barinas. Centromochlus schultzi. Brazil. Goiás State. MNRJ 12139, 10 of 38, $1 \mathrm{CS}, 85.0-108.9 \mathrm{~mm}$ SL, Serra da Mesa dam, upper rio 
Tocantins. Mato Grosso State. MNRJ 9417, 2, 32.7-60.8 mm SL, upper rio Xingu. Centromochlus simplex. Brazil. Mato Grosso State. MZUSP 47506, 1 CS, Igarapé do Aeroporto, Humboldt, Aripuanã. MZUSP 36862, 2, 28.4- 29.6 mm SL, rio Xingu. Tatia carolae. Guyana. USNM 401514, $37.2 \mathrm{~mm} \mathrm{SL}$, holotype of Tatia carolae Vari \& Ferraris, 2013, Rx, Cuyuni River, sand island in middle of river just downstream from Kurutuku, Essequibo river basin, Cuyuni-Mazaruni. USNM 401511, 1, 31.9 mm SL, paratype of Tatia carolae Vari \& Ferraris, 2013, Rx, Cuyuni River, sand and gravel beaches downstream from rapids at Kanaima Falls, Cuyuni- Mazaruni. Tatia melanoleuca. Brazil. Pará State. MNRJ $35521,1,48.5 \mathrm{~mm}$ SL, rio Tapajós, Mirituba along boat cross at Transamazônica, Itaituba. MZUSP 8535, 6, 1 CS, 46.9-76.5mm SL, rio Tapajós, Santarém. MZUSP 21837, 1, $38.5 \mathrm{~mm}$ SL, rio Tapajós, São Luiz. MZUSP 30585, 6, 1CS, 35.0- 48.4 mm SL, rio Tapajós, Alter do Chão. Tatia cf. melanoleuca. Brazil. Pará State. ANSP 196655, 1, $56.0 \mathrm{~mm}$ SL, rio Xingu, $4.5 \mathrm{~km}$ northeast of Vitória do Xingu, Senador José Porfírio. ANSP 196655, 1, 44.2 $\mathrm{mm}$ SL, rio Xingu, upstream of mouth of rio de Veiros, Porto de Moz. INPA 47841, 2, 49.7- 51.3 mm SL, rio Acarai, about $1 \mathrm{~km}$ above confluence with rio Xingu, Porto de Moz. Tatia musaica. Venezuela. Amazonas. AMNH 58795, 3, 25.1- 29.0 mm SL, paratypes, MBUCV-V 15663, $47.1 \mathrm{~mm} \mathrm{SL}$, holotype, MBUCV-V 17727, 1, 24.3 mm SL, paratype of Tatia musaica Royero, 1992, rio Atabapo, approximately $3 \mathrm{~km}$ from its mouth, San Fernando de Atabapo. ANSP 160656, 1, $57 \mathrm{~mm} \mathrm{SL}$, rio Sipapo, above Pendare. MCNG 21796, 1, 50.8 mm SL, caño La Chimita 3-15 $\mathrm{km}$ above confluence with rio Atacavi. Guyana. ANSP 175836, 9, 22.3- 30.5 mm SL, MNRJ 30491, 1, CS, 23.7 mm SL, Essequibo river. Brazil. Roraima state. MZUSP 9347, 1, 29.4 mm SL, rio Uraricoera, Maracá island, near Fazenda Canadá. Gelanoglanis stroudi. Colombia. Meta department. ANSP 142937, $22.6 \mathrm{~mm}$ SL, holotype of Gelanoglanis stroudi Böhlke, 1980, ANSP 142938, 5, 25.9-36.6 mm SL, paratypes of Gelanoglanis stroudi Böhlke, 1980, Rx, rio Metica approximately $22 \mathrm{~km}$ southwest from Puerto Lopez. FMNH 83912, 1, $24.6 \mathrm{~mm} \mathrm{SL}$, paratype of Gelanoglanis stroudi Böhlke, 1980, CS, rio Manacacias 4 km east from Puerto Gaitan. Gelanoglanis nanonocticolus. Brazil. Amazonas state. MZUSP 28308, 2, 16-16.8 mm SL, paratypes of Gelanoglanis nanonocticolus Soares-Porto, Walsh, Nico \& Maia Netto, 1999, Rx, Paraná do Jacaré, rio Negro, Amazon river basin. Glanidium albescens. Brazil. Minas Gerais State. MNRJ 16262, 4, 107.5-121.5 mm SL, rio Paraopeba, São Francisco river basin.

\section{Acknowledgements}

We wish to thank our colleagues at INMA and INPA for their assistance. For loans, exchange of specimens and/ or courtesies extended during visits to their institutions we thank Mark H. Sabaj Pérez (ANSP), Scott A. Schaefer (AMNH), Ramiro Royero (MBUCV-V), Donald Taphorn (MCNG), Paulo A. Buckup, Marcelo R. Britto (MNRJ), Heraldo A. Britski, Osvaldo T. Oyakawa, Michel Gianetti (MZUSP), Ronald de Ruiter (RMNH), Carl J. Ferraris Jr; Sandra Raredon, T. Griswold, Richard P. Vari (in memorian) (USNM). We acknowledge Carl J. Ferraris
Jr, Sandra Raredon for images and radiographs of Tatia carolae and the All Catfish Species Inventory Project http://acsi.acnatsci.org/ for availability of images of Tatia musaica. Thanks to Jansen Zuanon for initial suggestions on the diagnosis of C. orca, and to José Luiz O. Birindelli and Mark H. Sabaj for further comments and contributions on manuscript draft. We are also grateful to Wagner Fortes, Renata Frederico, Jonas Oliveira, Francinei Oliveira, and fishermen Manga and Mugico for the help in the field. Fieldwork supported by Biodinamica Rio Engenharia Consultiva during environmental licensing for construction of Transmission Line 500 KVa Oriximiná-Cariri. Study funded by Conselho Nacional de Desenvolvimento Científico e Tecnológico (CNPq) via Universal Project 471963/2013-5 and PCI- E1 grant 465023/2014-2 (to LMSS). Comparative material from rio Xingu made available by iXingu Project (NSF DEB-12578113).

\section{References}

Akama, A. 2004. Revisão sistemática dos gêneros Parauchenipterus Bleeker, 1862 e Trachelyopterus Valenciennes, 1840 (Siluriformes, Auchenipteridae). Unpublished Ph. D. thesis, Universidade de São Paulo, São Paulo, 375p.

Akama, A. \& L. M. Sarmento-Soares. 2007. Família Auchenipteridae. Pp. 116-120. In: Buckup, P. A., N. A. Menezes \& M. S. Ghazzi (Eds.). Catálogo das espécies de peixes de água doce do Brasil. Rio de Janeiro, Museu Nacional. (Série Livros, v. 23)

Birindelli, J. L. O. 2014. Phylogenetic relationships of the South American Doradoidea (Ostariophysi: Siluriformes). Neotropical Ichthyology, 12: 451-564.

Britski, H. A. 1972. Sistemática e evolução dos Auchenipteridae e Ageneiosidae (Teleostei, Siluriformes). Unpublished Ph. D. thesis, Universidade de São Paulo, São Paulo, 142p.

Dahdul, W. M., J. G. Lundberg, P. E. Midford, J. P. Balhoff, H. Lapp, T. J. Vision, M. A. Haendel, M. Westerfield \& P. M. Mabee. 2010. The teleost anatomy ontology: anatomical representation for the Genomics Age. Systematic Biology, 59: 369-383.

Ferraris, C. J., Jr. 1988. The Auchenipteridae: Putative monophyly and systematics, with a classification of the neotropical doradoid catfishes (Ostariophysi: Siluriformes). Unpublished Ph. D. thesis, The City University of New York, New York, 229p.

Ferraris, C. J., Jr. 2003. Family Auchenipteridae (driftwood catfishes). Pp. 470- 482. In: Reis, R. E., S. O. Kullander \& C. J. Ferraris, Jr. (Eds.). Check list of the freshwater fishes of South and Central America. Porto Alegre, Edipucrs.

Ferraris, C. J., Jr. 2007. Checklist of catfishes, recent and fossil (Osteichthyes: Siluriformes), and catalogue of siluriform primary types. Zootaxa, 1418: 1-628.

IUCN Standards and Petitions Subcommittee. 2016. Guidelines for Using the IUCN Red List Categories and Criteria. Version 12. Prepared by the Standards and Petitions Subcommittee. Downloadable from http://www.iucnredlist.org/documents/ RedListGuidelines.pdf. 
Royero, R. 1992. Tatia musaica, una nueva especie de bagre auquenipterido (Siluriformes -Auchenipteridae) de la cuenca del rio Orinoco, Territorio Federal Amazonas, Venezuela. Acta Cientifica Venezuelica, 43: 300-306.

Sarmento-Soares, L. M. \& J. L. O. Birindelli. 2015. A new species of the catfish genus Centromochlus (Siluriformes: Auchenipeteridae: Centromochlinae) from the upper rio Paraná basin, Brazil. Neotropical Ichthyology, 13:77-86.

Sarmento-Soares, L. M. \& P. A. Buckup. 2005. A new Glanidium from the Rio São Francisco basin, Brazil (Siluriformes: Auchenipteridae: Centromochlinae). Copeia, 2005: 846-853.

Sarmento-Soares, L. M. \& R. F. Martins-Pinheiro. 2008. A systematic revision of Tatia (Siluriformes: Auchenipteridae: Centromochlinae). Neotropical Ichthyology, 6: 495-542.

Sarmento-Soares, L. M. \& M. Porto. 2006. Comparative anatomy of the cheek muscles within the Centromochlinae subfamily (Ostariophysi, Siluriformes, Auchenipteridae). Journal of Morphology, 267: 187-197.

Soares-Porto, L. M. 1998. Monophyly and interrelationships of the Centromochlinae (Siluriformes, Auchenipteridae). Pp. 331-350. In: Malabarba, L. R., R. E. Reis, R. P. Vari, Z. M. S. Lucena \& C. A. S. Lucena (Eds.). Phylogeny and classification of Neotropical fishes. Porto Alegre, Edipucrs.

Tavolga, W. N. 1962. Mechanisms of sound production in the ariid catfishes Galeichthys and Bagre. Bulletin of the American Museum of Natural History, 124: 1-30.
Taylor, W. R. \& G. C. Van Dyke, 1985. Revised procedures for staining and clearing small fishes and other vertebrates for bone and cartilage study. Cybium, 9: 107-119.

Vanscoy, T., J. G. Lundberg \& K. R. Luckenbill. 2015. Bony ornamentation of the catfish pectoral-fin spine: comparative and developmental anatomy, with an example of fin-spine diversity using the tribe Brachyplatystomini (Siluriformes, Pimelodidae). Proceedings of the Academy of Natural Sciences of Philadelphia, 164:177-212.

Vari, R. P. \& B. B. Calegari. 2014. New species of the catfish genus Tatia (Siluriformes: Auchenipteridae) from the rio Teles Pires, upper rio Tapajós basin, Brazil. Neotropical Ichthyology, 12: 667-674.

Vari, R. P. \& C. J. Ferraris, Jr. 2013. Two new species of the catfish genus Tatia (Siluriformes: Auchenipteridae) from the Guiana Shield and a reevaluation of the limits of the genus. Copeia, 2013: 396-402.
Submitted March 13, 2016

Accepted August 29, 2016 by Marcelo Britto 
